\title{
SOSIALISASI DAN PENGEMBANGAN COURSE KOLABORATIF DAN EDUKATIF PADA SISTEM PEMBELAJARAN DARING (SPADA) BLENDED LEARNING BAGI PROGRAM STUDI HUBUNGAN INTERNASIONAL UNIVERSITAS MATARAM
}

(Socialization and Development of Collaborative and Educational Courses in Online Learning System (Spada) Blended Learning for Department of International Relations University of Mataram)

Ni Nyoman Wahyuni Indraswari ${ }^{[1]}$, Nadiyasari Agitha S.Kom., M.M.T. ${ }^{[1]}$, Mala Mardialina, S.IP., MA. ${ }^{[1,2]}$

${ }^{[1]}$ Dept of Informatics Engineering, University of

Mataram J1. Majapahit 62, Mataram, Lombok NTB,

INDONESIA ${ }^{[2]}$ Dept of International Relations,

University of Mataram J1. Majapahit 62, Mataram,

Lombok NTB, INDONESIA

Email: nunikyuni0300@gmail.com,nadiya@unram.ac.id,mala.mardialina@unram.ac.id

\begin{abstract}
Abstrak
Program Studi Hubungan Internasional Universitas Mataram (PRODI HI UNRAM) saat ini sedang mempersiapkan SPADA untuk turut serta membantu mencapai target LPMPP Universitas Mataram sekaligus sebagai alternatif metode pembelajaran jarakjauh. Namun, masalah utamanya adalah minimnya pemahaman dan akses informasi dosen dan mahasiswa terkait penggunaan fitur-fitur moodle pada website http://daring.unram.ac.id. Oleh karena itu perlu diadakannya sosialisasi untuk membantu pengembangan course kolaboratif dan edukatif Program Studi Hubungan Internasional dengan menggunakan blended learning. Pengembangan course kolaboratif dan edukatif dimulai dari perancangan modul setiap fitur-fitur selama 7 minggu. Sosialisasi modul course dengan dosen dilaksanakan sebanyak 2 sesi secara offline dan online. Sedangkan untuk sosialisasi modul course dengan mahasiswa dilaksanakan sebanyak 4 sesi secara offline. Untuk mengukur tingkat pemahaman dosen dan mahasiswa terkait modul course, diadakan pengisian kuesioner sebelum dan sesudah sosialisasi. Hasil dari perbandingan kuesioner tersebut menunjukkan bahwa sosialisasi penggunaan SPADA terbukti efektif terlihat dari peningkatan persentase kuesioner pada pengujian pemahaman dosen dan mahasiswa terkait keefektifan SPADA yang berkisar antara 16.7 sampai 20\% pada tingkat paham $(P)$ dan 33.3 sampai 35\% pada tingkat sangat paham (SP).
\end{abstract}

Keywords: Blended learning, Kuesioner SPADA, LPMPP, Universitas Mataram

\section{Pendahuluan}

\subsection{Latar Belakang}

Pada saat ini perkembangan ilmu dan teknologi semakin pesat, khususnya teknologi informasi dan telekomunikasi yang memberikan peranan penting dalam kehidupan manusia dalam banyak bidang [1]. SPADA atau Sistem Pembelajaran Daring merupakan salah satu program untuk implementasi Pendidikan Jarak Jauh pada Pendidikan Tinggi yang bertujuan untuk meningkatkan pemerataan akses terhadap pembelajaran yang bermutu [2].

Tentunya perubahan gaya belajar ini memunculkan berbagai macam effort dan tantangan baru yang harus dihadapi. Salah satunya pemilihan metode pembelajaran yang pas yaitu blended learning. Blended Learning lebih menekankan kepada penggabungan metode konvensional (face-to-face) dengan metode online, maka dari itu kesiapan keduanya adalah kunci utama keberhasilan dan kelancaran jalannya pembelajaran daring [3].

Lembaga Penjaminan Mutu dan Pengembangan Pendidikan (LPMPP) Universitas Mataram menginisiasi program "Pelatihan TOT Sistem Pembelajaran Daring (SPADA) Universitas Mataram” menggunakan Learning Management System pada SPADA Universitas Mataram dalam rangka menghadapi suasana pembelajaran di tengah pandemi Covid-19 [4].

Program Studi Hubungan Internasional Universitas Mataram (PRODI HI UNRAM) saat ini sedang mempersiapkan Sistem Pembelajaran Daring (SPADA) untuk turut serta membantu mencapai target LPMPP 
Universitas Mataram sekaligus sebagai alternatif metode pembelajaran jarak jauh. Namun, dikarenakan kompleksnya fitur pada platform Moodle yang digunakan membuat Program Studi Hubungan Internasional mengalami kesulitan untuk mengembangkan course yang bersifat kolaboratif dan edukatif bagi seluruh akademisi Program Studi Hubungan Internasional Universitas Mataram.

Oleh karena itu perlu diadakannya sosialisasi untuk membantu pengembangan course kolaboratif dan edukatif Program Studi Hubungan Internasional dengan menggunakan blended learning. Pengembangan course kolaboratif dan edukatif dimulai dari perancangan modul dari setiap fitur-fitur yang ada agar ke depannya para dosen, staf serta mahasiswa mampu mengoptimalkan penggunaan Sistem Pembelajaran Daring guna melancarkan kegiatan belajar mengajar dengan Mahasiswa khususnya di tengah situasi pandemi Covid-19.

\section{Tinjauan Pustaka}

\subsection{Internet}

Internet adalah jaringan global yang menghubungkan komputer di seluruh dunia. Dengan internet, sebuah komputer bisa mengakses data yang terdapat pada komputer lain di benua yang berbeda. Sebuah toko online bisa tetap terbuka selama 24 jam sehari dan 7 hari seminggu tanpa henti. Dengan internet, kejadian penting yang terjadi di suatu negara bisa segera diketahui oleh orang lain di negara yang berbeda[5].

\subsection{E-Learning}

E-Learning jika disebutkan secara sederhana adalah pembelajaran elektronik. Di mana, metode pembelajaran diberikan/disampaikan kepada pelajar dengan menggunakan media elektronik yang terkoneksi dengan internet (daring). Sebelumnya, Digital learning atau materi yang disediakan digital seperti penggunaan Video Player juga disebut e-Learning. Namun, dengan perkembangan teknologi, metode ini kini sudah disebut dengan digital learning [6].

\subsection{Learning Management System (LMS)}

Learning Management System (LMS) adalah sebuah platform yang digunakan untuk mengirimkan materi secara online yang diberikan oleh pengajar kepada seluruh pelajar. Tak hanya sebagai media untuk membagikan materi, sistem LMS juga dapat mengelola pelatihan dan pengembangan, meningkatkan keterlibatan pelajar dan juga mengembangkan interaksi antar pelajar. Pengajar pun dapat lebih memaksimalkan waktu untuk mendekatkan diri kepada pelajar dan menghapuskan semua jarak yang umumnya dirasakan di sekolah/kampus [7].

\subsection{Moodle}

Moodle (singkatan dari Modular Object-Oriented Dynamic Learning Environment) adalah paket perangkat lunak yang diproduksi untuk kegiatan belajar berbasis internet dan situs web yang menggunakan prinsip social constructionist pedagogy. Moodle merupakan salah satu aplikasi dari konsep dan mekanisme belajar mengajar yang memanfaatkan teknologi informasi, yang dikenal dengan konsep pembelajaran elektronik atau e-learning. Moodle dapat digunakan secara bebas sebagai produk sumber terbuka (open source) di bawah lisensi GNU. Moodle dapat di-install di komputer dan sistem operasi apa pun yang bisa menjalankan PHP dan mendukung database SQL. Moodle dikembangkan Martin Gougiamas, yang merupakan satu paket perangkat lunak. Platform learning moodle memakai model computer assisted learning dan computer assisted teaching. Terdapat dua model yang berada di moodle, sehingga disebut dengan LSM (Learning Management System) [8].

\subsection{Blended Learning}

Blended learning yaitu metode pembelajaran yang memadukan pertemuan tatap muka dengan materi online secara harmonis. Perpaduan antara pembelajaran konvensional di mana pendidik dan peserta didik bertemu langsung dengan pembelajaran secara online yang dapat diakses kapan saja dan di mana saja. Adapun bentuk lain dari blended learning adalah pertemuan virtual antara pendidik dengan peserta didik. Dimana antara pendidik dan peserta didik mungkin saja berada di dua tempat yang berbeda, namun bisa saling memberifeedback, bertanya, atau menjawab. Semuanya dilakukan secara real time [9].

\subsection{Pembelajaran Kolaboratif dan Edukatif}

Pembelajaran kolaboratif (collaborative learning) adalah suatu proses mengonstruksi pengetahuan melalui interaksi dengan memayungi suatu pendekatan pendidikan yang melibatkan usaha bersama siswa dengan siswa, atau siswa dengan guru bersama-sama. Pembelajaran edukatif adalah pembelajaran yang mencakup tentang hal- 
hal yang bersifat pengetahuan serta segala sesuatu yang bersifat mendidik, memberikan pembelajaran dan amanat [10].

\subsection{Flowchart}

Flowchart atau sering disebut dengan diagram alir merupakan suatu jenis diagram yang merepresentasikan algoritma atau langkah-langkah instruksi yang berurutan dalam sistem. Flowchart dapat membantu untuk memberikan solusi terhadap masalah yang bisa saja terjadi dalam membangun sistem. Pada dasarnya, flowchart digambarkan dengan menggunakan simbol-simbol. Setiap simbol mewakili suatu proses tertentu. Sedangkan untuk menghubungkan satu proses ke proses selanjutnya digambarkan dengan menggunakan garis penghubung [11].

\section{Metode Pengabdian masyarakat}

Pada pengabdian kepada masyarakat di Hubungan Internasional ini dilakukan analisis kebutuhan yang diperlukan dalam sosialisasi dan pengembangan course kolaboratif dan edukatif dengan tahapan pada Gambar 1 sebagai berikut:

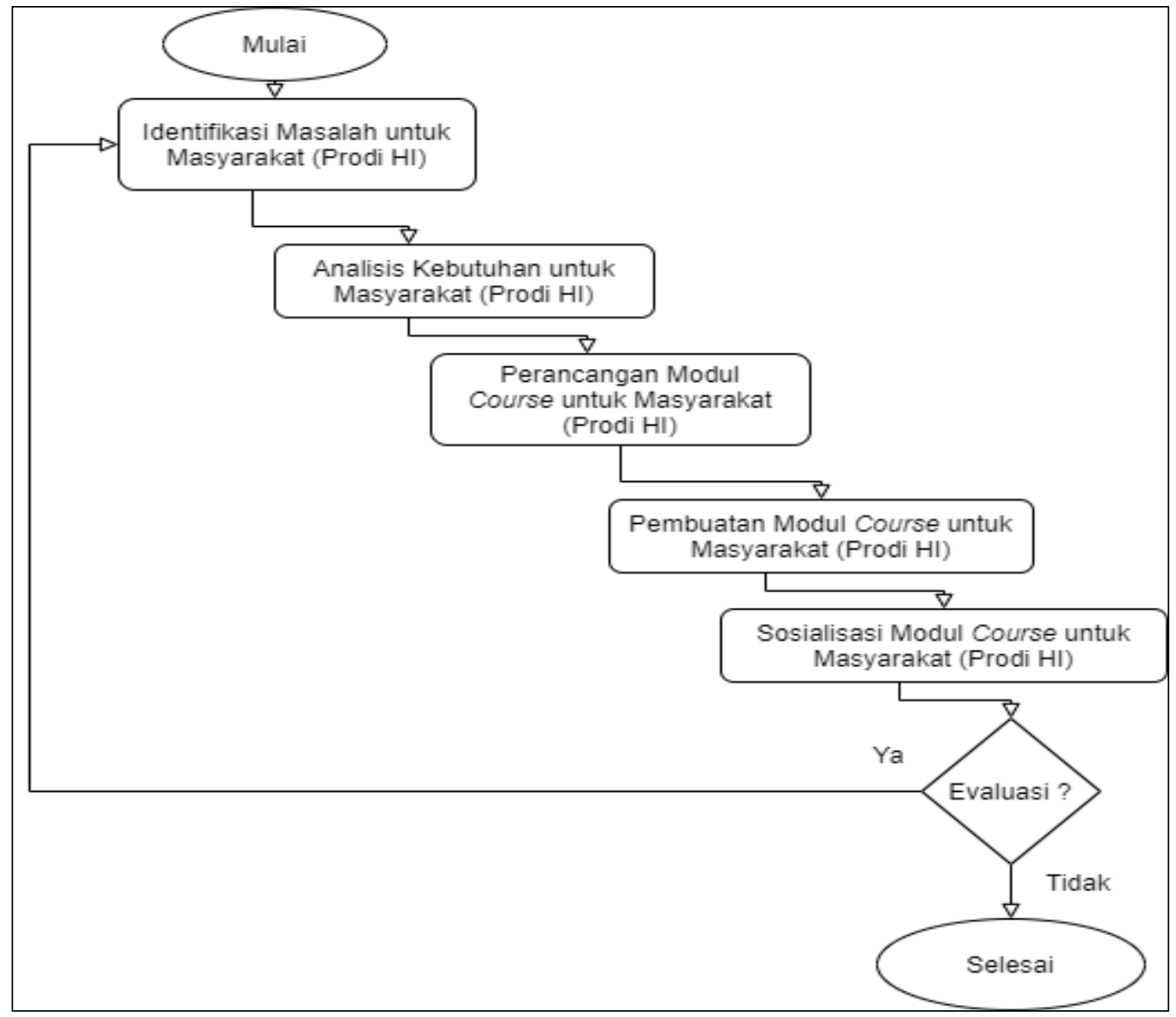

Gambar 1 Flowchart analisis kebutuhan.

\subsection{Identifikasi Masalah}

Setelah melakukan survei ke Program Studi Hubungan Internasional Universitas Mataram, permasalahan terkait penggunaan course melalui website http://daring.unram.ac.id dapat diringkas sebagai berikut :

1. Minimnya pemahaman dosen dan mahasiswa terkait penggunaan fitur-fitur moodle yang tersedia pada website http://daring.unram.ac.id.

2. Minimnya akses informasi di Internet terkait tata cara penggunaan fitur-fitur moodle yang lengkap.

\subsection{Analisis Kebutuhan}

Berdasarkan permasalahan di atas, hal-hal yang dibutuhkan sebagai berikut :

1. Kuesioner kepada dosen dan mahasiswa sebagai tolak ukur tingkat pemahaman penggunaan fitur-fitur moodle 
pada website http://daring.unram.ac.id.

2. Sebuah modul yang berisi tata cara penggunaan course secara lengkap pada website http://daring.unram.ac.id yang diharapkan mampu menjadi penunjang pemahaman dosen dan mahasiswa dalam mengoperasikannya.

\subsection{Perancangan Modul Course}

Berdasarkan analisa kebutuhan di atas, dapat disusun jadwal pembuatan modul course sebagai berikut :

1. Minggu Pertama

Pada minggu pertama pengabdian kepada masyarakat berlangsung pada tanggal 11 sampai 16 Januari 2021 secara online (work from home). Adapun agenda yang dilakukan pada minggu pertama meliputi pembuatan course, penambahan enrollment key course, penyuntingan course, pembuatan dan penyuntingan announcements serta pengecekan participants.

2. Minggu Kedua

Pada minggu kedua pengabdian kepada masyarakat berlangsung pada tanggal 18 sampai 23 Januari 2021 secara online (work from home). Adapun agenda yang dilakukan pada minggu kedua meliputi penambahan badges, pengaturan grades, pembuatan dan pengaturan attendance serta pembuatan dan penilaian assignment.

\section{Minggu Ketiga}

Pada minggu ketiga pengabdian kepada masyarakat berlangsung pada tanggal 25 sampai 30 Januari 2021 secara online (work from home). Adapun agenda yang dilakukan pada minggu ketiga meliputi pembuatan database, pengisian field database, pembuatan bigbluebuttonbn, testing bigbluebuttonbn dan pembuatan quiz.

4. Minggu Keempat

Pada minggu keempat pengabdian kepada masyarakat berlangsung pada tanggal 1 sampai 6 Februari 2021 secara online (work from home). Adapun agenda yang dilakukan pada minggu keempat meliputi tambah pertanyaan quiz, pembuatan file, pembuatan folder, mengunduh dan mengedit isi folder serta pembuatan page.

5. Minggu Kelima

Pada minggu kelima pengabdian kepada masyarakat berlangsung pada tanggal 8 sampai 13 Februari 2021 secara online (work from home). Adapun agenda yang dilakukan pada minggu kelima meliputi pembuatan forum, penambahan diskusi topik, pemberian grade peserta, pembuatan dan penambahan pertanyaan feedback.

6. Minggu Keenam

Pada minggu keenam pengabdian kepada masyarakat berlangsung pada tanggal 15 sampai 20 Februari 2021 secara online (work from home). Adapun agenda yang dilakukan pada minggu keenam meliputi pembuatan survey, pembuatan glossary, penambahan entri glossary, pembuatan book serta penambahan bab dan sub-bab book.

7. Minggu Ketujuh

Pada minggu ketujuh pengabdian kepada masyarakat berlangsung pada tanggal 22 sampai 27 Februari 2021 secara online (work from home). Adapun agenda yang dilakukan pada minggu ketujuh meliputi pembuatan label, pembuatan URL, pembuatan external tool serta pembuatan dan penggunaan chat.

\subsection{Pembuatan Modul Course}

\subsubsection{Agenda Pada Time Line Minggu Pertama}

Agenda pada time line minggu pertama diawali dengan pembuatan course dan penambahan enrollment key course seperti pada Gambar 2 dan Gambar 3. Pembuatan course dapat dimulai dengan memilih menu site home yang terletak pada kolom sebelah kiri. Selanjutnya, dosen dapat mengisi identitas wajib seperti nama lengkap dan kode nama course. Untuk pengaturannya dapat mengikuti default settings moodle atau ingin memodifikasi seperti pada buku panduan yang telah dibuat. Penambahan enrollment key bertujuan agar suatu course/mata kuliah terlindungi oleh sebuah kata kunci sehingga hanya mahasiswa tertentu saja yang dapat mengakses course/matakuliah tersebut. Dosen dapat menambah enrollment key dengan mengakses enrollment methods pada users. 


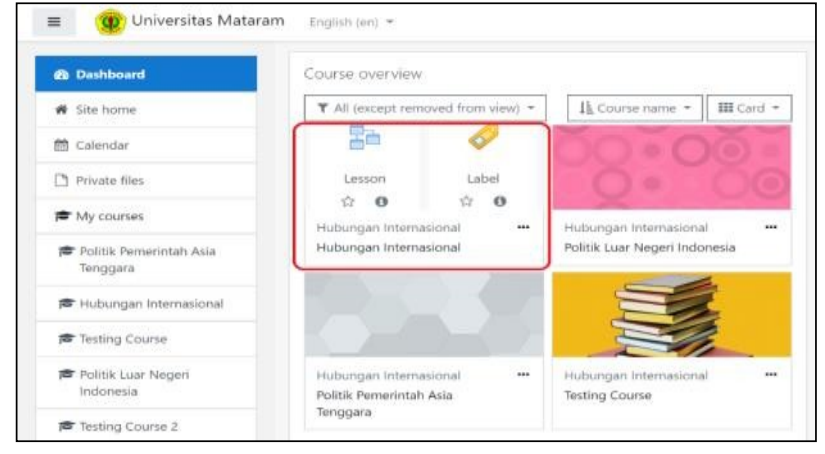

Gambar 2 Pembuatan Course

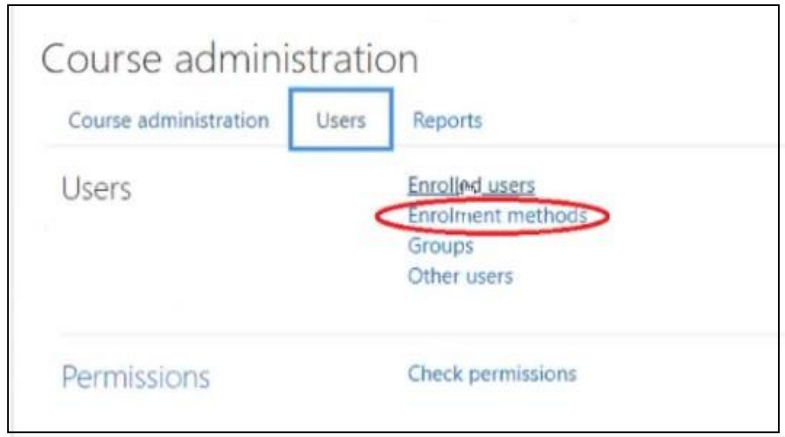

Gambar 3 Penambahan Enrollment Key Course.

\subsubsection{Agenda Pada Time Line Minggu Kedua}

Agenda pada time line minggu kedua diawali dengan pembuatan dan pengaturan attendance serta pembuatan assignment seperti pada Gambar 3 dan Gambar 4. Pembuatan attendance ditujukan untuk agar mahasiswa dapat melakukan presensi melalui http://daring.unram.ac.id. Status deskripsi, komponen penilaian dan batas waktu attendance dapat diatur melalui "Status set". Assignment merupakan tempat untuk mahasiswa mengumpulkan sesuatu, baik berupa tugas harian, essay, jawaban ujian, dan lain sebagainya. Dengan pembuatan assignment, dosen dapat dengan mudah mengkoordinir file-file dari mahasiswa secara efisien.

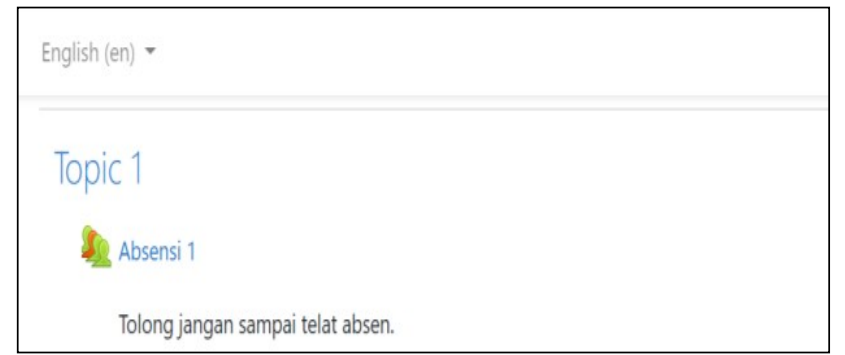

Gambar 4 Pembuatan dan Pengaturan Attendance.

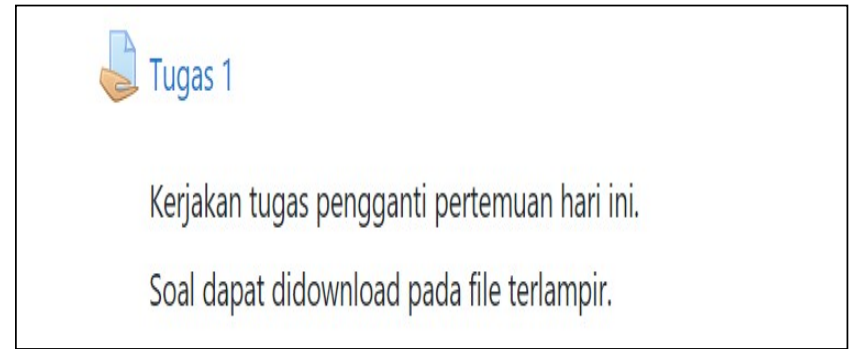

Gambar 5 Pembuatan Assignment.

\subsubsection{Agenda Pada Time Line Minggu Ketiga}

Agenda pada time line minggu ketiga diawali dengan pembuatan database dan quiz seperti pada Gambar 6 dan Gambar 7. Kegunaan database sama seperti pada umumnya, yaitu sebagai tempat penyimpanan. Pada moodle, database dapat digunakan oleh dosen untuk menampung bahan ajar seperti file materi, kumpulan soalsoal, folder, link website dan lain sebagainya. Database agar dapat digunakan harus mempunyai kolom-kolom entry untuk menyimpan data. Maka dari itu, untuk menambah entry dosen dapat memilih opsi "Add entry" dan mengisi detail informasi sesuai petunjuk pada panduan yang telah dibuatkan. Quiz merupakan kumpulan soal dengan tipe beragam yang dikerjakan dalam kurun waktu tertentu. Pada umumnya, quiz digunakan sebagai media ujian, latihan, dan lain sebagainya yang berhubungan dengan pengerjaan soal.

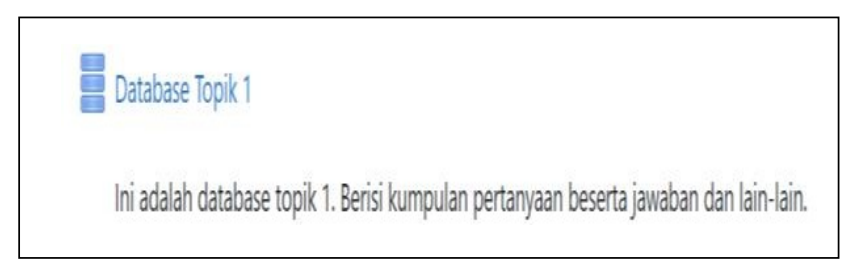

Gambar 6 Pembuatan Database.

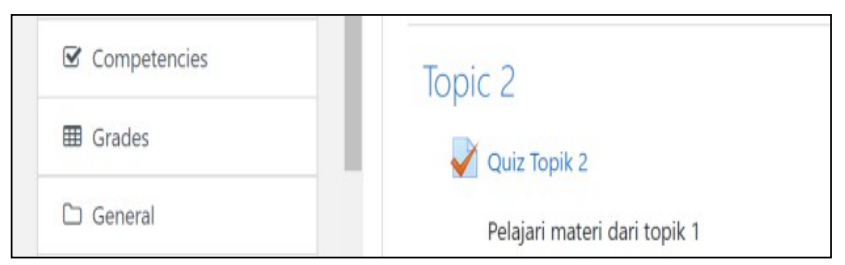

Gambar 7 Pembuatan Quiz.

\subsubsection{Agenda Pada Time Line Minggu Keempat}

Agenda pada time line minggu keempat diawali dengan pembuatan pertanyaan quiz dan file seperti pada Gambar 8 dan Gambar 9. Setelah tempat quiz dibuat, dosen dapat menambahkan soal-soal di dalamnya. Untuk menambahkan soal dapat memilih "a new question" pada menu "add". Terdapat banyak jenis tipe soal, mulai dari multiple choice, true / false, matching, short answer, numerical, essay, drag and drop into text, dan lain sebagainya. File pada moodle sama seperti kegunaan file pada umumnya, yang dimana merupakan suatu berkas 
yang dapat diakses. Bentuk file yang dapat diunggah dalam moodle bermacam-macam, dapat berupa .pdf, .pptx, .word, dan lain sebagainya

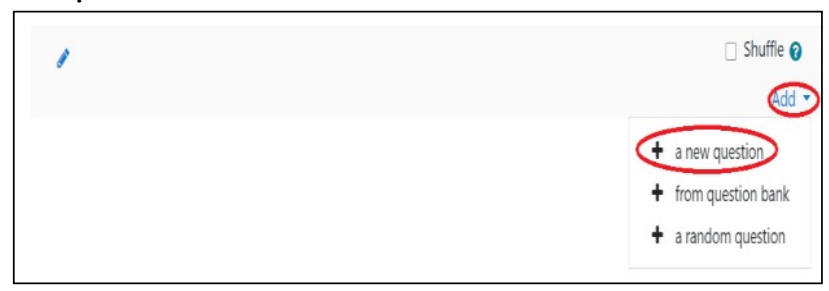

Gambar 8 Tambah Pertanyaan Quiz.

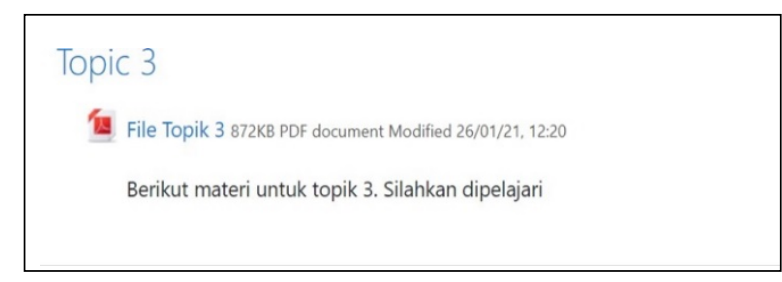

Gambar 9 Pembuatan File.

\subsubsection{Agenda Pada Time Line Minggu Kelima}

Agenda pada time line minggu kelima diawali dengan pembuatan forum dan feedback seperti pada Gambar 10 dan Gambar 11. Forum merupakan tempat dimana seluruh partisipan yang ada di dalam course dapat melakukan diskusi. Tidak hanya dengan dosen dan mahasiswa saja, tetapi diskusi juga dapat dilakukan antar mahasiswa. Melalui forum, mahasiswa juga dapat membuat topik diskusi sendiri . Seperti pembahasan sebelumnya dimana dosen dan mahasiswa juga dapat membuat topik diskusi sendiri, untuk menambah topik diskusi dosen dan mahasiswa dapat memilih "Add a new discussion topic". Pembuatan feedback serupa dengan kuesioner, dimana pembuat akan meminta responden untuk memberikan umpan terhadap sesuatu. Dosen dapat membuat feedback kepada mahasiswa untuk mengetahui tolak ukur kepuasan, penilaian terhadap course atau yang berkaitan dengan mata kuliah tersebut. Fitur feedback dapat dibuat dengan mengakses "Turn editing on".

Forum Pertemuan 5

Silahkan lakukan diskusi terkait pertemuan 5 pada forum ini.

Gambar 10 Pembuatan Forum.

\section{Nespon untuk Pertemuan 5}

Silahkan dijawab respon berikut sebagai bahan evaluasi untuk kedepannya.

Gambar 11 Pembuatan Feedback.

\subsubsection{Agenda Pada Time Line Minggu Keenam}

Agenda pada time line minggu keenam diawali dengan pembuatan survey dan glossary seperti pada Gambar 12 dan Gambar 13. Kegunaan fitur survey tidak sama dengan feedback. Survey dikhususkan untuk pengumpulan, pencatatan dan analisis dari informasi yang didapat terhadap subjek yang dalam hal ini adalah mahasiswa. Pada umumnya, dosen menggunakan survey untuk melakukan pengamatan terhadap sebuah kondisi atau segala bentuk kegiatan yang melibatkan mahasiswa. Sama seperti glosarium pada umumnya, fitur glossary pada moodle digunakan oleh dosen sebagai kamus singkat untuk menampung daftar istilah dari suatu kata yang berhubungan dengan materi dalam course.

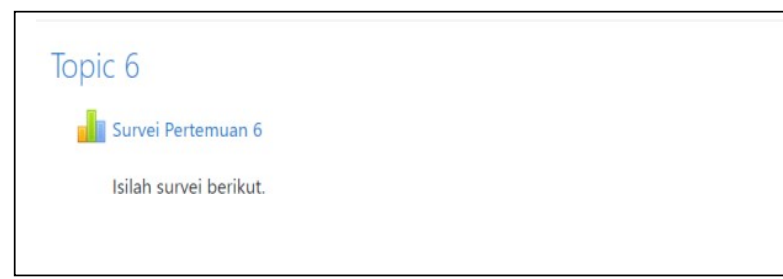

Gambar 12 Pembuatan Survey.

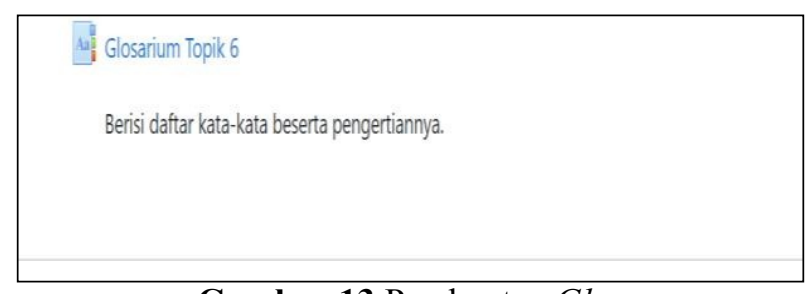

Gambar 13 Pembuatan Glossary.

\subsubsection{Agenda Pada Time Line Minggu Ketujuh}

Agenda pada time line minggu ketujuh diawali dengan pembuatan URL dan external tool seperti pada Gambar 14 dan Gambar 15. Course yang telah dibuat dapat disisipkan URL website lain untuk memudahkan dosen dalam memberi informasi yang lebih luas kepada mahasiswa. Penggunaan URL pada umumnya dapat berupa pemberian link video perkuliahan di channel youtube, akses menuju video conference, social media dan lain sebagainya. Sehingga dosen tidak perlu mengunggah file berukuran besar ke dalam sistem, cukup menghubungkan dengan link URL saja. Kegunaan external tool pada moodle serupa dengan kegunaan URL, yaitu mampu 
menghubungkan ke link website lain. Penggunaan external tool juga dapat menghubungkan dengan link video perkuliahan, akses menuju video conference, social media dan lain sebagainya. Perbedaannya adalah pada external tool terdapat fitur-fitur tambahan seperti keyword parameter sebagai kunci dari link website yang dimasukkan.

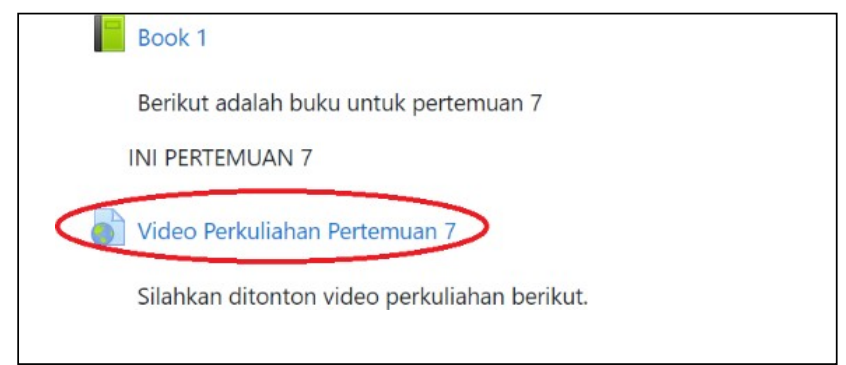

Gambar 14 Pembuatan External Tool.

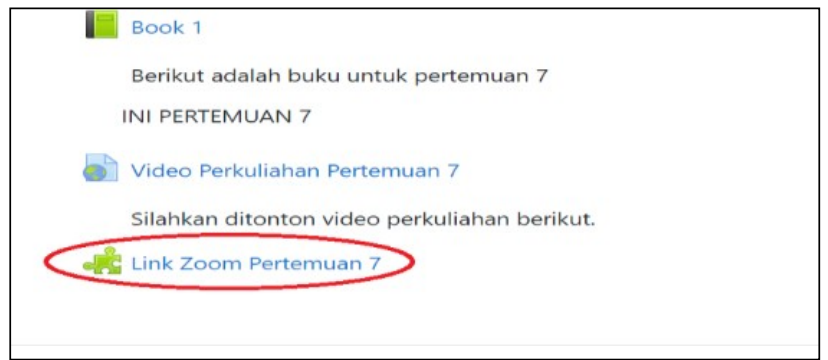

Gambar 15 Pembuatan URL.

\subsection{Sosialisasi Modul Course}

\section{Sosialisasi Penggunaan Sistem Pembelajaran Daring (SPADA) Dengan Dosen}

Sosialisasi pertama penggunaan Sistem Pembelajaran Daring (SPADA) dengan Dosen Program Studi Hubungan Internasional berlangsung secara offline pada tanggal 26 Februari 2021. Dosen yang hadir di tempat berjumlah 3 orang, namun yang terdokumentasi hanya pada saat berjumlah 2 orang seperti pada Gambar 16 . Sosialisasi kedua berlangsung secara online pada tanggal 16 Maret 2021 seperti pada Gambar 17. Dosen yang hadir di room zoom berjumlah 6 orang. Sosialisasi penggunaan SPADA diadakan kembali bersamaan dengan sosialisasi HIBAH agar dosen yang berhalangan hadir sebelumnya mendapatkan materi yang sama.

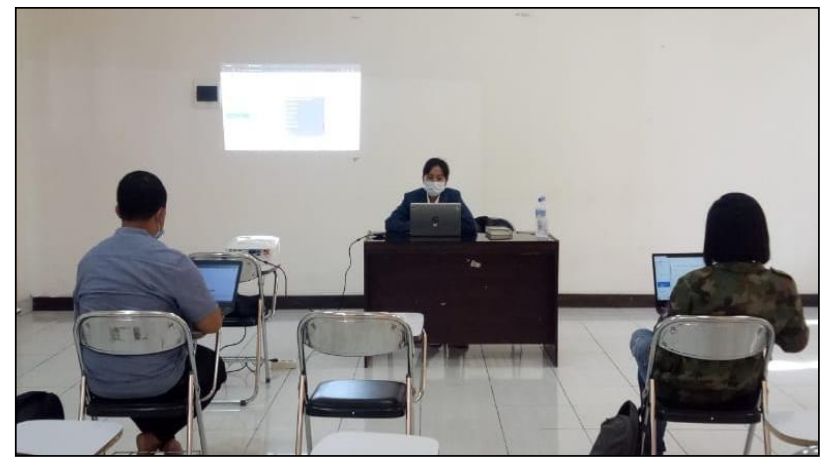

Gambar 16 Sosialisasi dengan dosen secara offline.

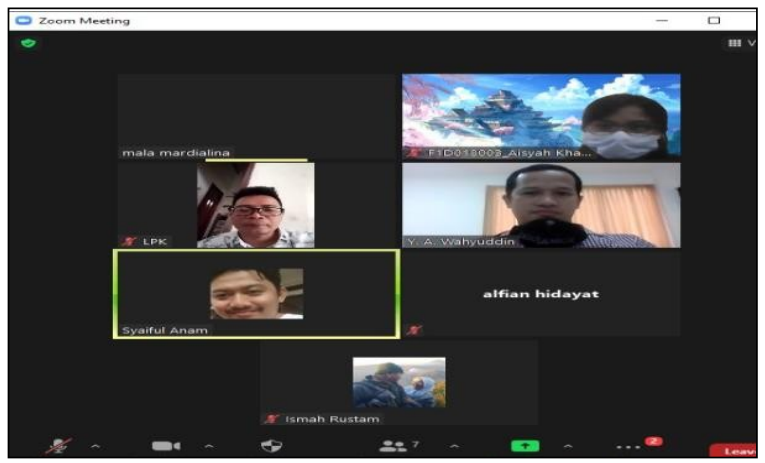

Gambar 17 Sosialisasi dengan dosen secara offline.

\section{Sosialisasi Penggunaan Sistem Pembelajaran Daring (SPADA) Dengan Mahasiswa}

Sosialisasi penggunaan Sistem Pembelajaran Daring (SPADA) dengan Mahasiswa Program Studi Hubungan Internasional berlangsung secara offline mulai tanggal 30 Maret sampai 1 April 2021. Kegiatan sosialisasi dibagi menjadi 4 sesi pertemuan. Sesi pertama dan kedua pada Gambar 18 dan Gambar 19 diikuti oleh angkatan 19 kelas A, B, C, sedangkan sesi ketiga dan keempat diikuti oleh angkatan 20 kelas A, B kedua pada Gambar 20 dan Gambar 21. Masing-masing kelas mengirim perwakilan sebanyak 10 orang.
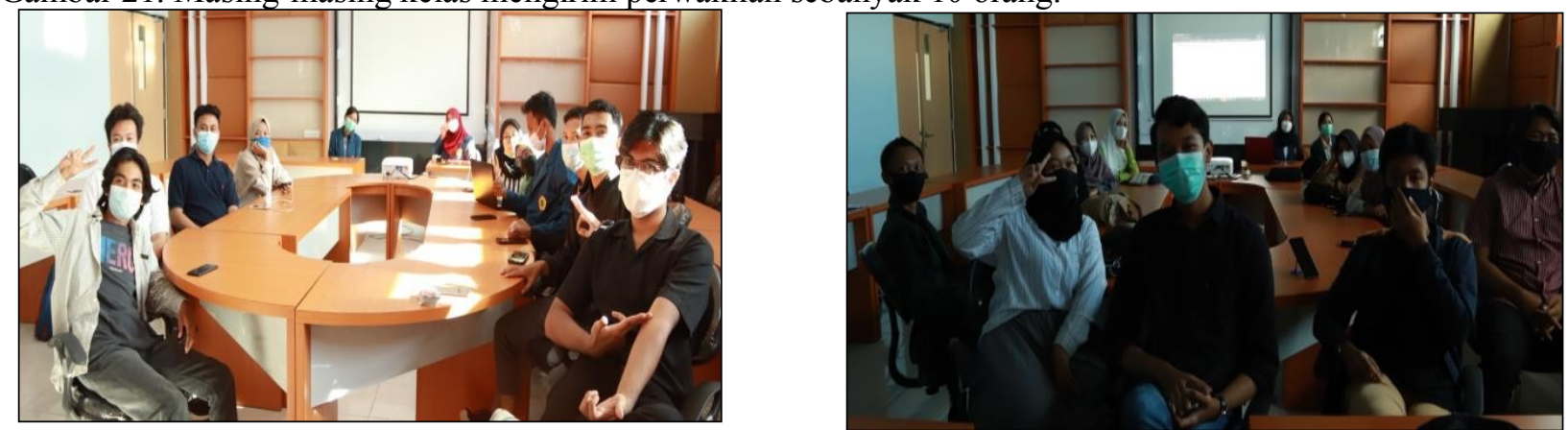

Gambar 18 Sosialisasi hari pertama dengan Mahasiswa. Gambar 19 Sosialisasi hari kedua dengan Mahasiswa. 

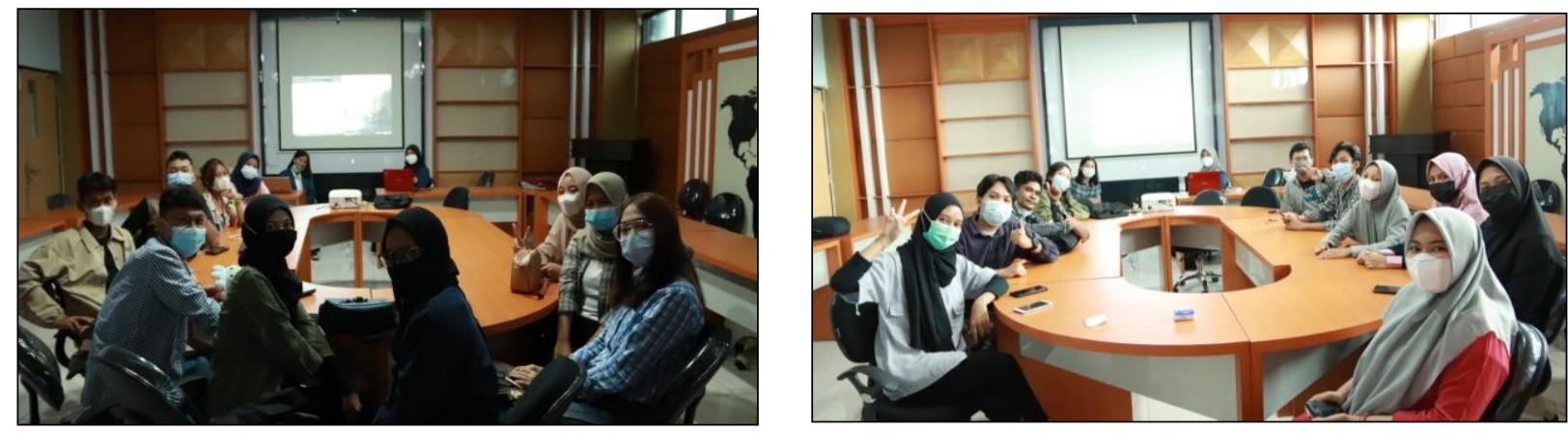

Gambar 20 Sosialisasi hari ketiga dengan Mahasiswa. Gambar 21 Sosialisasi hari keempat dengan Mahasiswa.

\section{Hasil dan Pembahasan}

\subsection{Perbandingan Kuesioner Dosen Sebelum dan Sesudah Sosialisasi \\ 1. Pengujian Pemahaman SPADA}

Pada Gambar 22 dan Gambar 23 dapat dilihat bahwa pada grafik lingkaran sebelum dan sesudah dilakukannya sosialisasi menunjukkan perbedaan signifikan. Hal ini dapat dibuktikan melalui meningkatnya persentase pemahaman dari total 6 responden pada tingkat paham (P) sebesar 33.3\% dan sangat paham (SP) sebesar $16.7 \%$. Berdasarkan hal tersebut dapat disimpulkan bahwa sosialisasi dapat meningkatkan pemahaman responden terkait apa itu Sistem Pembelajaran Daring (SPADA).

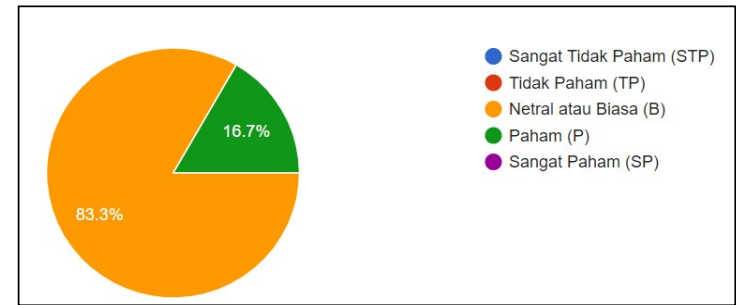

Gambar 22 Pengujian Pemahaman SPADA SPADA Sebelum Sosialisasi.

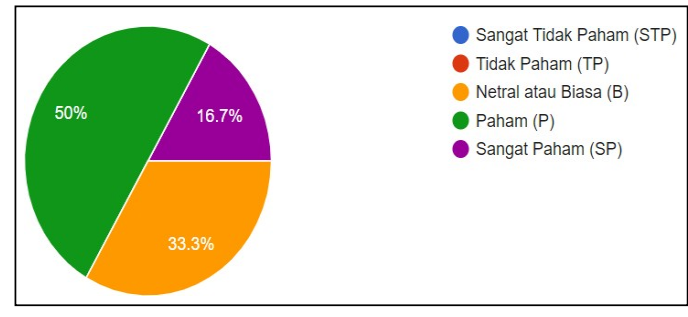

Gambar 23 Pengujian Pemahaman Sesudah Sosialisasi.

\section{Pengujian Pemahaman Komponen Kolaborasi Pembelajaran Menarik}

Pada Gambar 24 dan Gambar 25 dapat dilihat bahwa pada grafik lingkaran sebelum dan sesudah dilakukannya sosialisasi menunjukkan perbedaan yang cukup signifikan. Hal ini dapat dibuktikan melalui penurunan tingkat persentase tidak pemahaman (TP) dengan total 6 responden yang awalnya sebesar 33.3\%, setelah dilakukan sosialisasi menjadi $0 \%$. Selain itu, meningkatnya persentase pemahaman pada tingkat paham sebesar $33.3 \%$ dan sangat paham (SP) sebesar 16.7\%. Berdasarkan hal tersebut dapat disimpulkan bahwa sosialisasi dapat meningkatkan pemahaman responden terkait kegunaan komponen yang berhubungan dengan penggabungan video, audio, teks dan lain sebagainya pada Sistem Pembelajaran Daring (SPADA) Universitas Mataram.

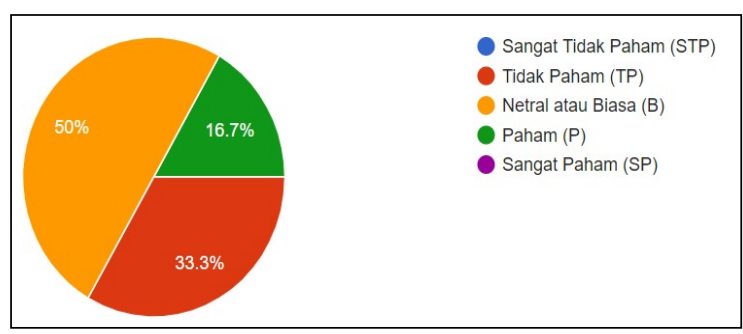

Gambar 24 Pengujian Pemahaman Komponen Pembelajaran Menarik Sebelum Sosialisasi.

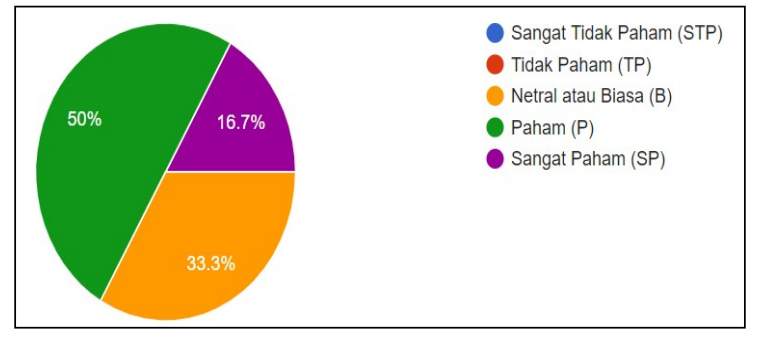

Gambar 25 Pengujian Pemahaman Komponen Kolaborasi Kolaborasi Pembelajaran Menarik Sesudah Sosialisasi. 


\section{Pengujian Keefektifan SPADA}

Pada Gambar 26 dan Gambar 27 dapat dilihat bahwa pada grafik lingkaran sebelum dan sesudah dilakukannya sosialisasi menunjukkan perbedaan signifikan. Hal ini dapat dibuktikan melalui meningkatnya persentase pemahaman dari total 6 responden pada tingkat paham (P) sebesar $16.7 \%$ dan sangat paham (SP) sebesar 33.3\%. Berdasarkan hal tersebut dapat disimpulkan bahwa sosialisasi dapat meningkatkan kemudahan akademisi dalam melakukan kegiatan belajar dan mengajar menggunakan Sistem Pembelajaran Daring (SPADA).

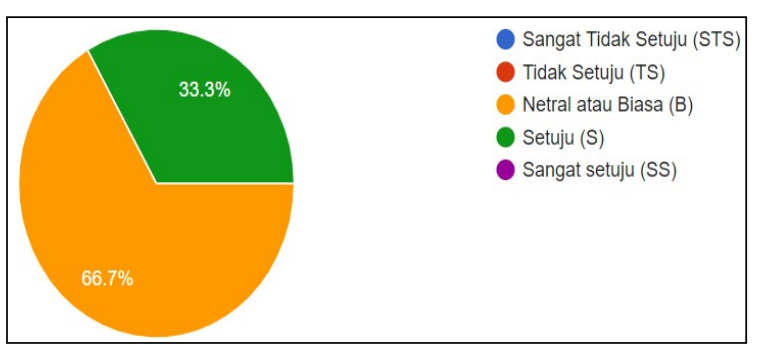

Gambar 26 Pengujian Keefektifan SPADA SPADA Sebelum Sosialisasi.

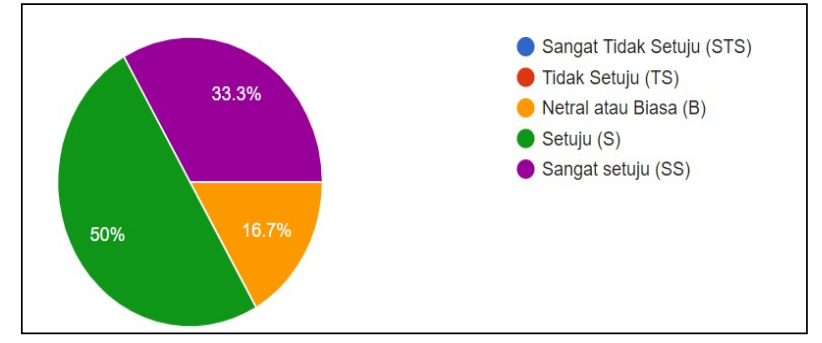

Gambar 27 Pengujian Keefektifan Sesudah Sosialisasi.

\subsection{Perbandingan Kuesioner Mahasiswa Sebelum dan Sesudah Sosialisasi}

\section{Pengujian Pemahaman SPADA}

Pada Gambar 28 dan Gambar 29 dapat dilihat bahwa pada grafik lingkaran sebelum dan sesudah dilakukannya sosialisasi menunjukkan perbedaan signifikan. Hal ini dapat dibuktikan melalui meningkatnya persentase pemahaman dari total 20 responden pada tingkat sangat paham (SP) sebesar 65\%. Berdasarkan hal tersebut dapat disimpulkan bahwa sosialisasi dapat meningkatkan pemahaman responden terkait apa itu Sistem Pembelajaran Daring (SPADA).

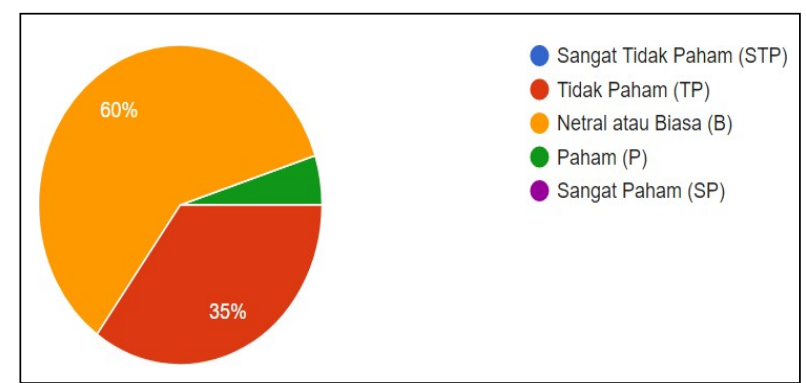

Gambar 28 Pengujian Pemahaman SPADA SPADA Sebelum Sosialisasi.

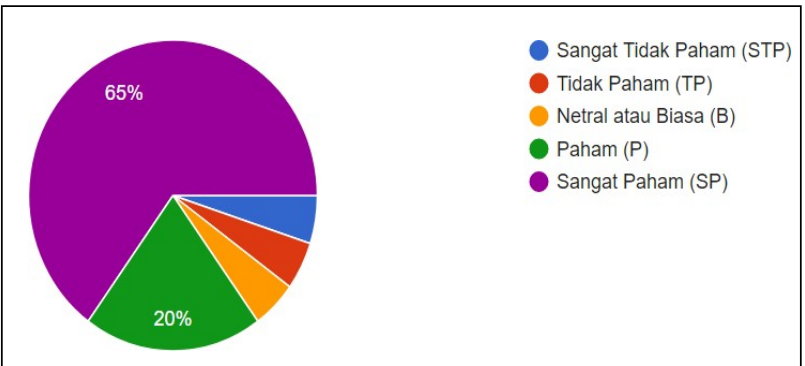

Gambar 29 Pengujian Pemahaman Sesudah Sosialisasi.

\section{Pengujian Keefektifan SPADA}

Pada Gambar 30 dan Gambar 31 dapat dilihat bahwa pada grafik lingkaran sebelum dan sesudah dilakukannya sosialisasi menunjukkan perbedaan signifikan. Hal ini dapat dibuktikan melalui meningkatnya persentase pemahaman dari total 20 responden pada tingkat paham (P) sebesar 20\% dan sangat paham (SP) sebesar 35\%. Berdasarkan hal tersebut dapat disimpulkan bahwa sosialisasi dapat meningkatkan kemudahan mahasiswa dalam melakukan kegiatan belajar menggunakan Sistem Pembelajaran Daring (SPADA).

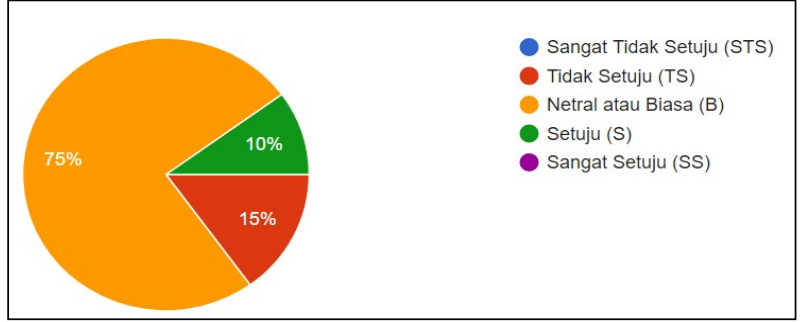

Gambar 30 Pengujian Keefektifan SPADA SPADA Sebelum Sosialisasi.

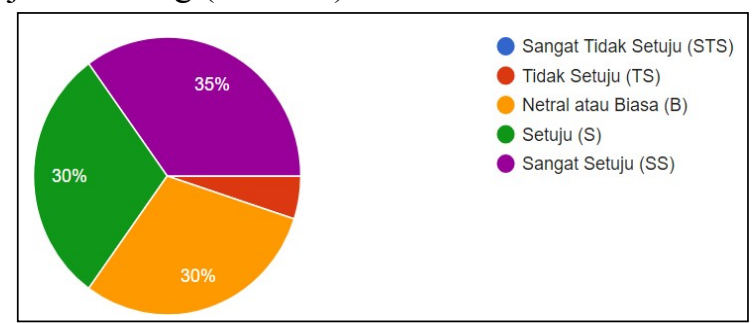

Gambar 31 Pengujian Keefektifan Sesudah Sosialisasi. 


\section{KESIMPULAN DAN SARAN}

\subsection{Kesimpulan}

Dengan adanya sosialisasi penggunaan Sistem Pembelajaran Daring (SPADA) Universitas Mataram dan pembuatan modul course sebagai bekal penunjang kepada dosen dan mahasiswa Program Studi Hubungan Internasional Universitas Mataram dapat meningkatkan pemahaman dari segi kegunaan fitur-fitur pada moodle yang dapat membantu kelancaran kegiatan belajar dan mengajar di tengah pandemi Covid-19. Hal ini terbukti dari peningkatan persentase kuesioner pada pengujian pemahaman dosen dan mahasiswa terkait keefektifan Sistem Pembelajaran Daring (SPADA) yang berkisar antara 16.7 sampai 20\% pada tingkat paham (P) dan 33.3 sampai $35 \%$ pada tingkat sangat paham (SP).

Adapun saran yang dapat diberikan penulis agar ke depannya lebih baik lagi yaitu meningkatkan jumlah sosialisasi kepada dosen selaku pembuat fitur-fitur pada moodle agar kegiatan belajar dan mengajar secara kolaboratif dan edukatif lebih optimal, membuat media alternatif selain modul course yang dapat dijadikan sebagai penunjang pemahaman oleh dosen dan mahasiswa dan menggencarkan intensitas penyebaran kuesioner agar jumlah responden lebih banyak dan perhitungan perbandingan persentase lebih optimal.

\section{UCAPAN TERIMA KASIH}

Ucapan terima kasih kepada instansi Program Studi Hubungan Internasional Universitas Mataram yang telah memberikan kesempatan melakukan kegiatan penelitian dan pengabdian masyarakat. Rekan-rekan staf, dosen dan mahasiswa yang memberikan data dan informasi untuk dijadikan sebagai bahan dasar untuk pembuatan modul course. Serta kepada keluarga dan teman-teman yang membantu penulis dalam melaksanakan penelitian dan pengabdian ini.

\section{DafTAR PUSTAKa}

[1] B. Adipura, "Pengaruh Model pembelajaran Sains-Teknologi-Masyarakat dalam Meningkatkan Literasi Sains dan Teknologi ditinjau dari Gaya Kognitif Siswa," Al-Tadzkiyyah J. Pendidik. Islam, vol. 8, pp. 75-83, 2012, [Online]. Available: https://media.neliti.com/media/publications/177430-IDperan-teknologi-informasi-dan-komunikasi.pdf.

[2] Admin, "APA itu SPADA INDONESIA," Spada Indonesia, 2015. https://spada.kemdikbud.go.id/berita/apa-itu-spada-indonesia\# (accessed Apr. 13, 2021).

[3] C. R. Graham and S. Allen, "Blended Learning Environments," Encycl. Distance Learn., no. January 2007, pp. 172-179, 2011, doi: 10.4018/978-1-59140-555-9.ch024.

[4] Admin, "Pelatihan TOT SPADA : Optimis Raih Target 51\% Mata Kuliah di Unram Berbasis E-Learning," Universitas Mataram, 2020. https://unram.ac.id/pelatihan-tot-spada-optimis-raih-target-51-mata-kuliahdi-unram-berbasis-e-learning/ (accessed Apr. 13, 2021).

[5] P. Hidayatullah, Pemrograman Web, Ed. Revisi. Bandung: Informatika : BANDUNG, 2017.

[6] Y. M. Putra, U. M. Buana, R. J. Putri, and U. M. Buana, "SISTEM INFORMASI MANAJEMEN Pengembangan Sistem Informasi Dosen : Yananto Mihadi Putra, SE, M . Si," no. October, 2019.

[7] T. Panyajamorn, S. Suanmali, Y. Kohda, P. Chongphaisal, and T. Supnithi, "Effectiveness of E-Learning Design in Thai Public Schools," Malaysian J. Learn. Instr., vol. 15, no. 1, pp. 1-34, 2018.

[8] R. N. Hidayah, "MEMBANGUN WEBSITE E-LEARNING DENGAN MOODLE PADA SMK ADI SUMARMO PROGRAM KEAHLIAN TEKNIK KOMPUTER DAN JARINGAN (TKJ),” pp. 274-282, 2015.

[9] H. Handoko and W. Waskito, Blended Learning: Konsep dan Penerapannya, vol. 5, no. 2. 2018.

[10] S. P. Retno Dewi, "Pembelajaran Kolaboratif Di Saat Pandemi Covid-19," 2021. http://pena.belajar.kemdikbud.go.id/2021/01/pembelajaran-kolaboratif-di-saat-pandemi-covid-19/ (accessed Apr. 13, 2021).

[11] I. A. Ridlo, "Pedoman Pembuatan Flowchart," Academia.Edu, p. 27, 2017, [Online]. Available: academia.edu/34767055/Pedoman_Pembuatan_Flowchart. 